\title{
The making of a soufflé : practical knowledge and social senses
}

Nathan Schlanger

\section{(2) OpenEdition \\ 12 Journals}

Electronic version

URL: https://journals.openedition.org/tc/740

DOI: $10.4000 /$ tc.740

ISSN: 1952-420X

Publisher

Éditions de l'EHESS

\section{Printed version}

Date of publication: 1 September 1991

ISSN: 0248-6016

\section{Electronic reference}

Nathan Schlanger, "The making of a soufflé : practical knowledge and social senses", Techniques \& Culture [Online], 15 | 1991, Online since 12 January 2006, connection on 29 September 2022. URL: http://journals.openedition.org/tc/740 ; DOI: https://doi.org/10.4000/tc.740

This text was automatically generated on 29 September 2022.

All rights reserved 
The making of a soufflé : practical knowledge and social senses

Nathan Schlanger 